\title{
Evidence for the Involvement of More Than One mRNA Species in Controlling the Inactivation Process of Rat and Rabbit Brain $\mathrm{Na}$ Channels Expressed in Xenopus Oocytes
}

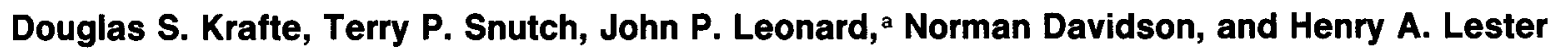 \\ Division of Biology, California Institute of Technology, Pasadena, California 91125
}

\begin{abstract}
The properties of rat and rabbit brain sodium $(\mathrm{Na})$ channels expressed in Xenopus oocytes following either unfractionated or high-molecular-weight mRNA injections were compared to assess the relative contribution of different size messages to channel function. RNA was size-fractionated on a sucrose gradient and a high-molecular-weight fraction (7-10 kilobase) encoding the $\alpha$-subunit gave rise to functional voltage-dependent $\mathrm{Na}$ channels in the oocyte membrane. Single-channel conductance, mean open time, and time to first opening were all similar to the values for channels following injection of unfractionated RNA. In contrast, inactivation properties were markedly different; $\mathrm{Na}$ currents from high-molecular-weight RNA inactivated with a severalfold smaller macroscopic inactivation rate and showed a steady-state voltage dependence that was shifted in the depolarizing direction by at least $10 \mathrm{mV}$ relative to that for unfractionated RNA. Single-channel recording revealed that the kinetic difference arose from a greater probability for high-molecular-weight RNA induced channels to reopen during a depolarizing voltage step. Pooling all gradient fractions and injecting this RNA into oocytes led to the appearance of $\mathrm{Na}$ channels with inactivation properties indistinguishable from those following injection of unfractionated RNA. These results suggest that mRNA species not present in the highmolecular-weight fraction can influence the inactivation process of rat brain $\mathrm{Na}$ channels expressed in Xenopus oocytes. This mRNA may encode $\beta$-subunits or other proteins that are involved in posttranslational processing of voltage-dependent $\mathrm{Na}$ channels.
\end{abstract}

Voltage-dependent sodium (Na) channels have been recognized as an integral component of neural functioning since Hodgkin and Huxley (1952) identified their role in the depolarizing phase of the squid axon action potential. Since these pioneering experiments, major advances have been made in understanding how Na channels function using a variety of electrophysiological, biochemical, and pharmacological techniques. Recent pro-

\footnotetext{
Received July 21, 1987; revised Jan. 15, 1988; accepted Jan. 18, 1988.

We wish to thank M. Fearey for technical assistance, F. Shon for assistance with the computer programs, and W. A. Catterall for the gift of $\alpha$-scorpion toxin. This work was supported by NS-11756, GM-10991, an NRSA individual fellowship (D.S.K.), and fellowships from the American Heart Association Greater Los Angeles Affiliate (T.P.S. and J.P.L.).

Correspondence should be addressed to Dr. Douglas Krafte, Division of Biology 156-29, California Institute of Technology, Pasadena, CA 91125.

a Present address: P.O. Box 4348, Department of Biologcial Sciences MC/066, University of Illinois at Chicago, Chicago, IL 60680.

Copyright (C) 1988 Society for Neuroscience $0270-6474 / 88 / 082859-10 \$ 02.00 / 0$
}

gress includes purification and reconstitution of the major proteins of the channel (see Agnew, 1984, for review) and cloning of cDNAs encoding the $\alpha$-subunit of the channel complex (Noda et al., 1984, 1986a; Auld et al., 1988). Several additional questions can now be addressed regarding mechanisms of channel function within the cell.

As purified, the voltage-dependent $\mathrm{Na}$ channel from rat brain consists of 3 subunits: $\alpha(260 \mathrm{kDa}), \beta 1(36 \mathrm{kDa})$ and $\beta 2(33$ $\mathrm{kDa}$ ) (Hartshorne et al., 1982). After Xenopus oocytes are injected with in vitro transcripts of cDNAs encoding one type of rat brain $\alpha$-subunit, voltage-dependent $\mathrm{Na}$ channels appear in the oocyte membrane (plasmids of the RII series; Noda et al., 1986a, b; Stuhmer et al., 1987). A similar result is obtained with size fractions of mRNA that encode the $\alpha$-subunit (Goldin et al., 1986).

Although it is thus clear that RNA encoding only the $\alpha$-subunit can inducc functional $\mathrm{Na}$ channels in oocytes, there remain questions about other influences on $\mathrm{Na}$ channel function. (1) Various treatments, such as proteolysis, patch excision, and exposure to several classes of drugs, result in much slower inactivation kinetics, whether measured at the single-channel or macroscopic level (see, for example, Gonoi and Hille, 1987). Do all these agents affect only the $\alpha$-subunit? (2) The role played by $\beta$-subunits has remained unclear. The linkage of $\beta 2$ to $\alpha$ is temporally correlated with the membrane insertion of a functional channel complex (Schmidt and Catterall, 1986). Treatments that remove $\beta 1$ subunits from the purified brain channel also prevent functional reconstitution (Messner and Catterall, 1986; Messner et al., 1986). (3) The Na channel protein is phosphorylated both by cAMP-dependent protein kinase and by protein kinase C (Costa et al., 1982; Costa and Catterall, 1984a, b). There are no clear data on whether this phosphorylation affects the functional properties of the channel. Other uncertainties pertain especially to data obtained with the oocyte expression system. (4) Is the oocyte itself contributing subunits or modifications? (5) What properties prevent the oocyte from robustly expressing another rat brain message (synthesized from the RI plasmids of Noda et al., 1986a, b) or the TTX-resistant property of mammalian heart Na channels (Sutton et al., 1987)?

To help address these questions, we have continued to apply the technique of reconstitution by expression in Xenopus oocytes, particularly in conjunction with RNA fractionation techniques as pioneered by Sumikawa et al. (1984). In this study, we compare the properties of channels induced by injection of unfractionated mRNA versus the size fraction encoding the $\alpha$ subunit; the results enable one to assess the relative importance of different size messages in controlling the properties of these channels. We find that additional mRNA(s), not present in the 
Table 1. Composition of solutions

\begin{tabular}{lcccc} 
Component & $\begin{array}{l}\text { OR-2 } \\
(\mathrm{mM})\end{array}$ & $\begin{array}{l}\mathrm{P} / \mathrm{S} \\
(\mathrm{mM})\end{array}$ & $\begin{array}{l}\text { Normal } \\
\text { saline } \\
(\mathrm{mM})\end{array}$ & $\begin{array}{l}\text { osop } \\
(\mathrm{mm})\end{array}$ \\
\hline $\mathrm{NaCl}$ & 82.5 & 96.0 & 96.0 & 10.0 \\
$\mathrm{KCl}$ & 2.0 & 2.0 & 2.0 & 90.0 \\
$\mathrm{MgCl}_{2}$ & 1.0 & 1.0 & 1.0 & - \\
$\mathrm{CaCl}_{2}$ & - & 1.8 & 1.8 & - \\
$\mathrm{HEPES}$ & 5.0 & 5.0 & 5.0 & 10.0 \\
$\mathrm{pH}$ & 7.5 & 7.5 & 7.5 & 7.4 \\
Penicillin & - & $100 \mathrm{U} / \mathrm{ml}$ & - & - \\
Streptomycin & - & $100 \mu \mathrm{g} / \mathrm{ml}$ & - & - \\
Na-pyruvate & - & 2.5 & - & - \\
Theophylline & - & 0.5 & - & - \\
EGTA & - & - & - & 10.0
\end{tabular}

All values are given in mm unless otherwise indicated. osop, outside-out patch.

fraction encoding the $\alpha$-subunit, are indeed necessary to induce channels with "normal" inactivation properties, i.e., properties close to those induced by injection of unfractionated RNA. Preliminary accounts of these results have been published as abstracts (Krafte et al., 1987a, b).

\section{Materials and Methods}

The methods for RNA extraction, oocyte preparation, and injection are as described previously (Leonard et al., 1987). Briefly, RNA was extracted from the brains of 15 - to 18 -d-old rats or 10- to 22-d-old rabbits by a modified lithium chloride/urea procedure (Dierks et al., 1981). Poly $(\mathrm{A}+)$ RNA was prepared by oligo-dT chromatography using oligodT cellulose type III (Collaborative Research) (Maniatis et al., 1982) with the modification described by Leonard et al. (1987). Poly(A+) RNA was resuspended in sterile water at a concentration of $1-2 \mathrm{mg} / \mathrm{ml}$ for oocyte injections and/or sucrose gradient fractionation.

Adult female Xenopus laevis were anesthetized with $0.17 \%$ MS- 222 (tricaine methanesulfonate, Sigma Chemical Co.), and a section of the ovary was surgically removed. The tissue was bathed in $0.2 \%$ collagenase in OR-2 for 2.5-3.5 hr on an orbital shaker (see Table 1 for solution compositions). This treatment removed the follicle layer on $>50 \%$ of the oocytes. Stage V and VI oocytes were then selected and placed in $\mathrm{P} / \mathrm{S}$ solution for 4-24 hr before injection. Oocytes were injected with $50-70 \mathrm{ng}$ of poly $(\mathrm{A}+) \mathrm{RNA}$ and incubated for $2-4 \mathrm{~d}$ in P/S solution before recording (see below for the amount of fractionated RNA injected).

The sucrose gradient fractionation has been described by Goldin et al. (1986). Poly(A+) RNA, 100-200 $\mu$ g, was centrifuged through a linear 6-20\% sucrose gradient containing $15 \mathrm{~mm}$ Pipes, pH 6.4, $5 \mathrm{~mm}$ EDTA, and $0.25 \%$ Sarkosyl. The centrifugation was at $24,000 \mathrm{rpm}$ and $4{ }^{\circ} \mathrm{C}$ for $18 \mathrm{hr}$ in an SW27.1 rotor. The gradient was dripped into $\approx 0.5 \mathrm{ml}$ fractions, and each fraction was then ethanol-precipitated, washed twice with $70 \% \mathrm{EtOH}$, and resuspended in $50-100 \mu \mathrm{l}$ of sterile $\mathrm{H}_{2} \mathrm{O}$. The RNA from consecutive fractions, in groups of 3 , was then pooled and used for gel blots and oocyte injections. We typically injected $70 \mathrm{nl}$ of this pooled RNA which contained an amount of size-specific RNA equivalent to that found in 140-350 ng of unfractionated RNA depending on the volume in which the pooled RNA was resuspended.

The RNA gel blots and preparation of ${ }^{32} \mathrm{P}-\mathrm{Na}$ channel probes were as described by Goldin et al. (1986).

Recording was done in normal saline (see Table 1) using either a 2-microelectrode voltage clamp or patch clamp. For the 2-microelectrode recordings, both voltage and current electrodes were filled with 3 $\mathrm{M} \mathrm{KCl}$ and had resistances of approximately $1 \mathrm{M} \Omega$. Patch rccording configurations were as described by Hamill et al. (1981). The only additional manipulation necessary for patching was to remove the vitelline membrane from the oocyte. This was done by placing the oocyte in hypertonic normal saline (normal saline $+100 \mathrm{mM} \mathrm{NaCl}$ ) for approximately 5-10 min. The vitelline membrane separated from the plasma membrane as the oocyte shrunk and was removed manually with fine forceps. Pipettes were filled with normal saline for cell-attached patches and outside-out patch solution for excised outside-out patches (see Table 1). Pipettes for both recording configurations had resistances of 10-20 $\mathrm{M} \Omega$. In the cell-attached mode, a $3 \mathrm{M} \mathrm{KCl}$ voltage electrode was used to record oocyte resting potential. The command potential was subtracted from the resting potential using a differential amplifier and the result led to the command input of the patch clamp. We therefore knew the absolute potential across the patch. Data were filtered at $2 \mathrm{kIIz}$ with a 4-pole Bessel filter and digitized at $10-25 \mathrm{kHz}$. Data acquisition and analysis used the pCLAMP software package (Kegel et al., 1985; Axon Instruments, Burlingame, CA) for both 2-microelectrode and patch experiments. The voltage was held at $-100 \mathrm{mV}$ for $3 \mathrm{~min}$ to eliminate slow inactivation before the recordings were started, and all experiments were performed at $20-22^{\circ} \mathrm{C}$.

Time constants for inactivation were determined by fitting a single exponential plus a haseline to the decaying phase of the $\mathrm{Na}$ current records. Steady-state current was defined as the baseline to which the exponential function decayed.

Series resistance $\left(R_{s}\right)$ can be a major source of error when measuring large currents in large cells such as Xenopus oocytes (see Finkel and Gage, 1985, for a detailed discussion). Activation of large currents during depolarizing voltage steps can reduce the membrane resistance as channels open and give a significant voltage drop across $R_{s}$ as large currents flow. In both cases, the accuracy of the voltage clamp is compromised. To test for series resistance artifacts during our experiments, we measured the inactivation rates and voltage dependence of steadystate inactivation before and after adding $15 \mathrm{~nm}$ TTX, which reduced current amplitudes significantly. Comparable time constants and steadystate voltage dependence were observed in both cases. We still felt it important, however, to confirm our macroscopic observations with the higher-resolution single-channel recording technique, where series resistance does not constitute a significant problem.

A spontaneously active channel was observed in some of the cellattached patches; the conductance was $26 \mathrm{pS}$ and the current reversed near $-20 \mathrm{mV}$. This is most likely the stretch-activated channel reported by Methfessel et al. (1986). The activity was usually greatest immediately after forming a seal and in some patches then subsided. These were the patches used for the cell-attached data. Spontaneously active channels were rarely observed in excised outside-out patches. Similar observations have been reported by Methfessel et al. (1986).

$\alpha$-Scorpion toxin ( $\alpha$-ScTx) was a gift from W. A. Catterall. All other chemicals were obtained from Sigma Chemical $\mathrm{Co}$.

\section{Results}

\section{$R N A$ fractionation}

mRNA was fractionated by size on a sucrosc gradicnt as dcscribed in Materials and Methods. Figure 1 shows a Northern blot and a ${ }^{32} \mathrm{P}-$ poly $(\mathrm{dT})$ blot of the fractions from a typical gradient using rat brain mRNA. In both panels of Figure 1, A indicates unfractionated mRNA run as a control, while pools 1-11 are the specific gradient fractions, with pool 1 containing the largest mRNAs. Figure $1 A$ was obtained by hybridizing with ${ }^{32} \mathrm{P}$-labeled transcripts of cDNAs encoding regions of the $\alpha$-subunit message of the $\mathrm{Na}$ channel (see Materials and Methods, and Goldin et al., 1986). The distinct bands in fractions 3 and 4 illustrate the location of the intact $\alpha$-subunit within the gradient. Figure $1 B$ shows the result of a ${ }^{32} \mathrm{P}$-poly $(\mathrm{dT})$ blot from the same gradient and indicates the relative size and amount of the poly $(\mathrm{A}+)$ mRNA in each fraction. There are 2 important points to note here. First, those fractions containing the $\alpha$-subunit mRNA are free of detectable low-molecular-weight mRNAs [ $<5$ kilobasc]. Sccond, injection of pools 3 or 4 into Xenopus oocytes resulted in the appearance of functional $\mathrm{Na}$ channels (see below).

\section{Expression of functional Na channels from unfractionated and high-molecular-weight RNA}

Figure 2 shows representative 2-microelectrode records of $\mathrm{Na}$ currents following injection of unfractionated rat or rabbit brain poly $(\mathrm{A}+)$ RNA $(A$ and $D)$ and following injection of sucrose 
gradient fractions containing the $\alpha$-subunit message as described above $(B$ and $E)$. In all cases, robust inward currents were recorded in response to voltage steps from a holding potential of $-100 \mathrm{mV}$ to test potentials more positive than $-40 \mathrm{mV}$. The maximal current amplitude was generally smaller for high-molecular-weight (high-MW) RNA fractions compared with unfractionated RNA, probably for 2 reasons: (1) some Na channel RNA was degraded during the gradient manipulations, and (2) Na channel RNA was spread among 2 or more high-MW fractions. We therefore injected 2-5 times the equivalent amount of high-MW rat brain RNA than for an unfractionated sample, i.e., the equivalent of 140-350 ng of unfractionated RNA (see Materials and Methods).

There was generally less loss of activity for rabbit brain RNA than for rat brain RNA during fractionation. High-MW rabbit brain RNA was resuspended at twice the concentration of unfractionated rabbit brain RNA. The comparable current amplitudes shown in Figure 2, $D, E$, indicate that recovery of activity was quite good for this fractionation.

Comparison of the traces in Figure 2 for unfractionated versus high-MW recordings reveals that the macroscopic inactivation of current following high-MW RNA injection is substantially slower than that for unfractionated RNA. Figure 2, $C, E$, illustrate this point directly by superimposing records elicited by voltage steps to $-10 \mathrm{mV}$. In Figure $2 C$ the unfractionated trace has been scaled down by a factor of $2.45 \times$ so that the peaks superimpose, whereas no scaling was necessary in Figure $2 F$. The slower inactivation was noted at all potentials where inward $\mathrm{Na}$ currents were elicited. These kinetic differences were noted consistently in each of 23 separate batches of oocytes with 6 separate sucrose gradient fractionations over a period of $>1 \mathrm{yr}$. Table 2 gives values for the time constant of inactivation of rat $\mathrm{Na}$ channels before and after fractionation. In addition, the ratio of steady-state to peak inward current is also given. More maintained current was present for high-MW induced currents than for unfractionated RNA induced currents.

\section{Single-channel recordings confirm slower inactivation rates}

Despite the consistent qualitative differences we observed with the 2-microelectrode technique, the temporal resolution of this method in a Xenopus oocyte is insufficient for a quantitative characterization of Na current kinetics (see Leonard et al., 1986; Methfessel et al., 1986), primarily due to the large membrane capacitance of the oocyte. We therefore used patch-clamp recording to extend our observations. All single-channel observations were made on oocytes injected with rat brain RNA.

Figure 3 shows single $\mathrm{Na}$ channel recordings from oocytes injected with high-MW RNA or unfractionated RNA in both the cell-attached and outside-out configurations. Comparison of the records in each configuration shows that, in general, unfractionated RNA gives rise to $\mathrm{Na}$ channels that tend to open once and to cluster near the beginning of the voltage step. HighMW RNA gives Na channels that reopen during the step. The general tendency was for channel open times to be similar in all cases (see Table 3 below), although some excised patches did show openings that were longer than those in the cell-attached configuration (see Fig. 3, high-MW outside-out patch, for example). Figure 3 also presents ensemble average traces that reconstruct the macroscopic waveforms. The results are consistent with our 2-microelectrode recordings: high-MW RNA induces waveforms with slower macroscopic inactivation than those induced by unfractionated RNA in both configurations.
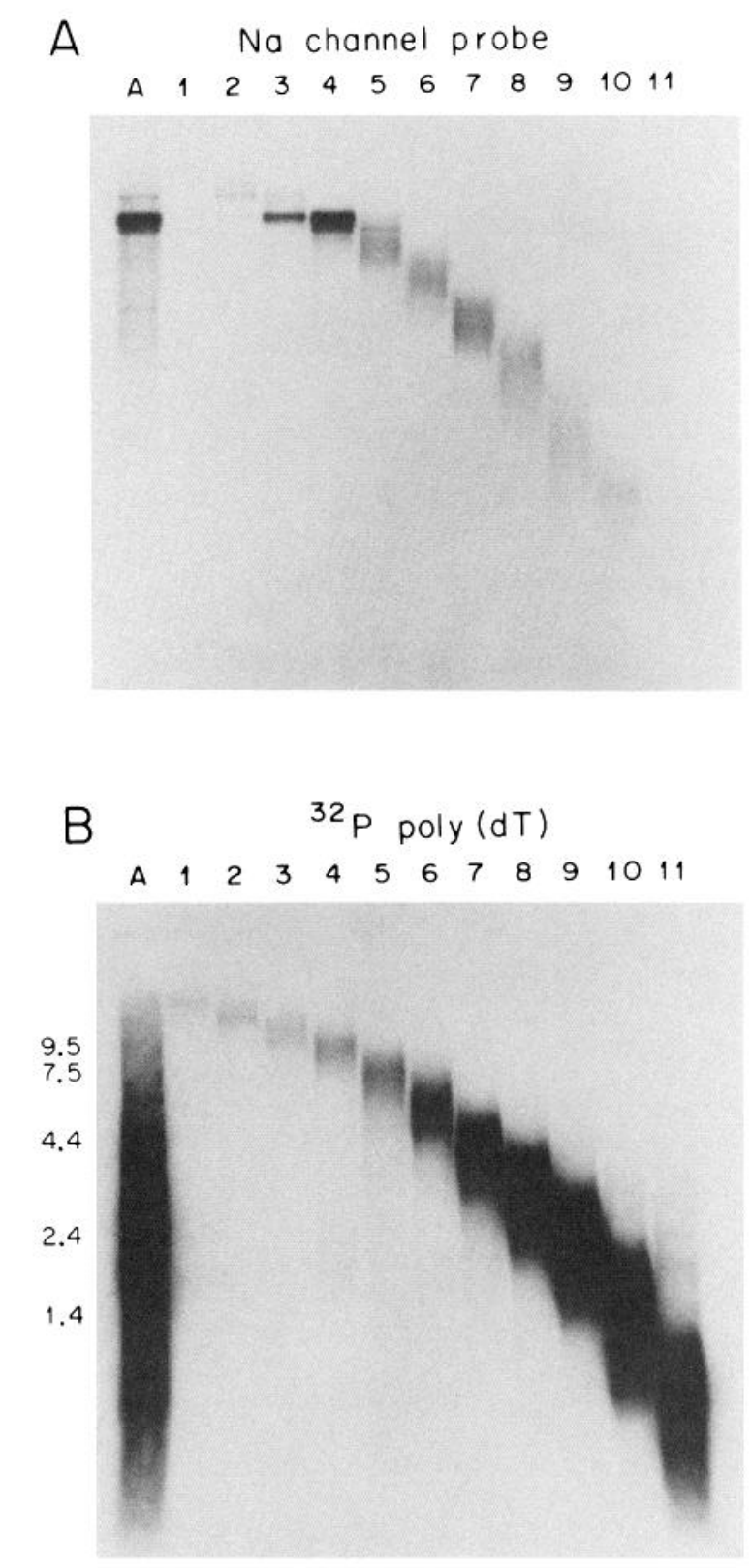

Figure 1. Gel blots of rat brain RNA fractions from a sucrose gradient. RNA was fractionated, electrophoresed, and transferred to Hybond N as described in Materials and Methods and by Goldin et al. (1986). Blots in $A$ were hybridized with Na channel $\alpha$-subunit probes (pEAF1 and pEAF8); those in $B$ with ${ }^{32} \mathrm{P}$-poly(dT). In both panels, A denotes unfractionated message and 1-11 are consecutive fractions from a sucrose gradient, with 1 containing the largest messages. Size markers (in kilobases) are given in the left-hand column of $B$.

\section{Single-channel conductance, mean open time, and first latency are similar for high $M W$ versus unfractionated RNA induced Na channels}

Our major goal for acquiring patch-clamp data was to confirm our results with the 2-microelectrode recordings in terms of macroscopic inactivation rates. In addition, the single-channel data also allow an initial comparison of the microscopic gating properties for channels arising from either unfractionated or high-MW RNA.

Table 3 presents the mean open time versus test potential for Na channels induced by unfractionated and high-MW RNA in 


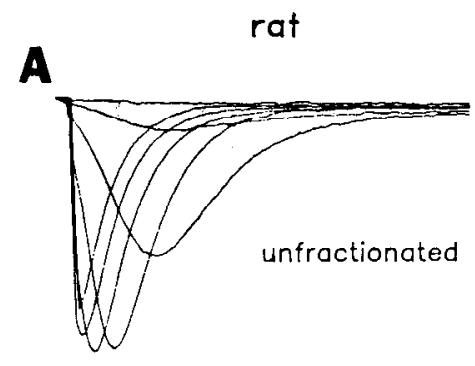

Figure 2. Sodium currents induced by unfractionated $(A, D)$ and high-MW $(B$, $E)$ rat and rabbit brain RNA. Na currents were elicited by voltage steps from a holding potential of $-100 \mathrm{mV}$. The test potential ranged from -50 to +10 $\mathrm{mV}$ for $A$ and to $+20 \mathrm{mV}$ for $B$ and from $-40 \mathrm{mV}$ to $+10 \mathrm{mV}$ in $D$ and $E$. In $C$ and $E$, individual traces from unfractionated and high-MW records elicited by a voltage step to $-10 \mathrm{mV}$ are replotted for comparison. The unfractionated trace in $C$, which inactivates more quickly, has been scaled down by a factor of 2.45. All records were obtained by subtracting the current remaining after application of $500 \mathrm{~nm}$ TTX from that before TTX. Calibration bars: amplitudes $-A, 735 \mathrm{nA} ; B$, $300 \mathrm{nA} ; D$ and $E, 980 \mathrm{nA}$; time $-A-C$, $2 \mathrm{msec}$; $D-E, 5 \mathrm{msec}$.
B

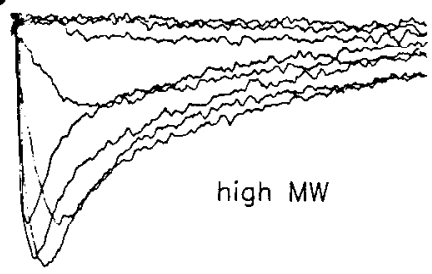

C

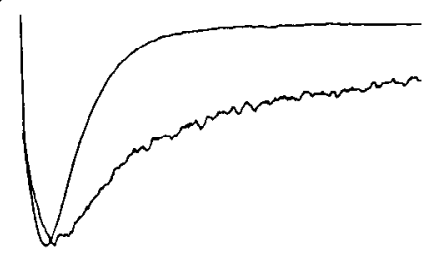

D

rabbit
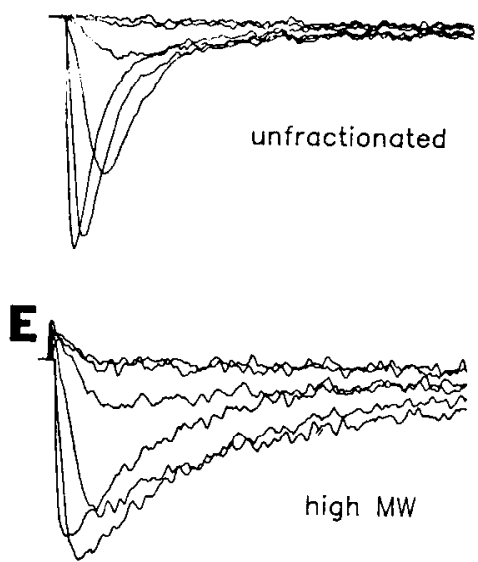

$\mathbf{F}$

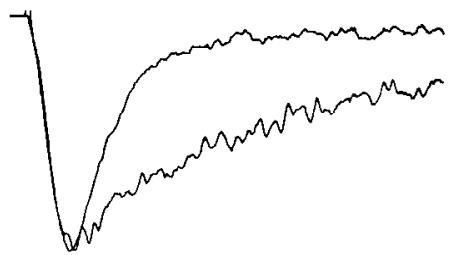

both cell-attached and excised outside-out patches. Values ranged from 0.47 to 1.15 msec over a voltage range of -40 to -10 $\mathrm{mV}$. There was no major difference in the mean open time between channels arising from either RNA type in the majority of patches studied, however. Figure 4 shows the open channel distribution for unfractionated and high-MW induced channels in the cell-attached configuration. The distributions are well fit by a single exponential, with the high-MW distribution giving a slightly longer mean open time ( $1.1 \mathrm{vs} 0.9 \mathrm{msec}$ ).
Figure $5 A$ presents a single-channel current-voltage curve for high-MW and unfractionated RNA induced Na channels in both recording configurations. In all cases the data are well fit by a linear current-voltage relationship over the voltage range -50 to $0 \mathrm{mV}$ with a conductance of $12 \mathrm{pS}$.

Figure $5 B$ shows a comparison of the first latency distribution for both high-MW and unfractionated RNA induced channels in a cell-attached patch containing a single channel (see Fig. 5 legend). Fits of a single exponential to the data for both un-

$$
\text { cell-attached patch }
$$

Figure 3. Single-channel records from unfractionated and high-MW rat brain RNA induced $\mathrm{Na}$ channels in cell-attached and outside-out patch configurations. All currents were elicited by voltage steps from a holding potential of $-100 \mathrm{mV}$ to a test potential of -20 $\mathrm{mV}$ for $12 \mathrm{msec}$. The test interval is denoted by the dashed line. Capacitive and resistive components, obtained by averaging all records without openings, were subtracted. Each set of records consists of consecutive episodes from a single trial. Below each column is the ensemble average (60-240 sweeps) of all records with openings. The ensemble waveforms have been scaled to similar amplitudes. Calibration bars; 1 pA, $3 \mathrm{msec}$. high MW

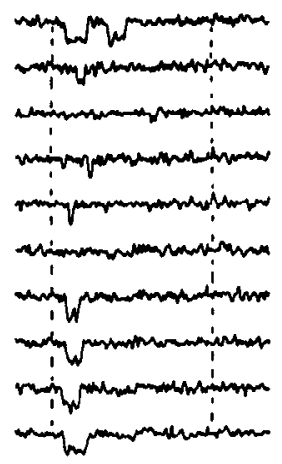

unfractionated
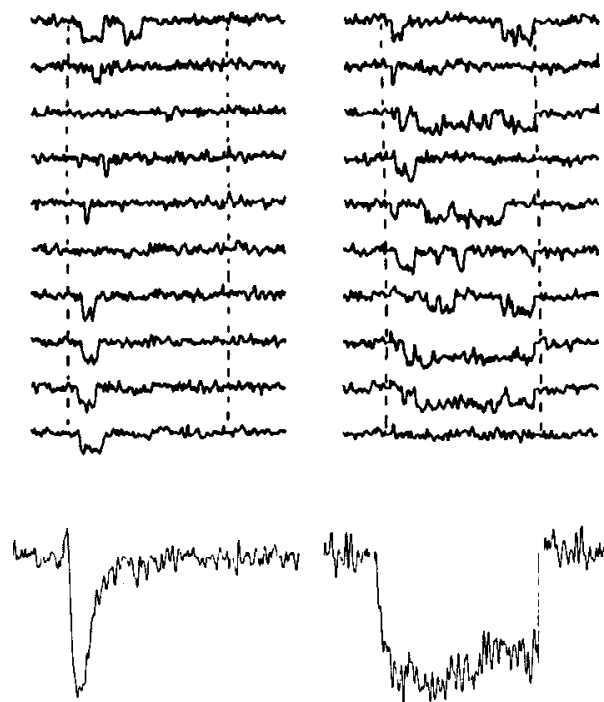

outside-out patch

unfractionated

high MW
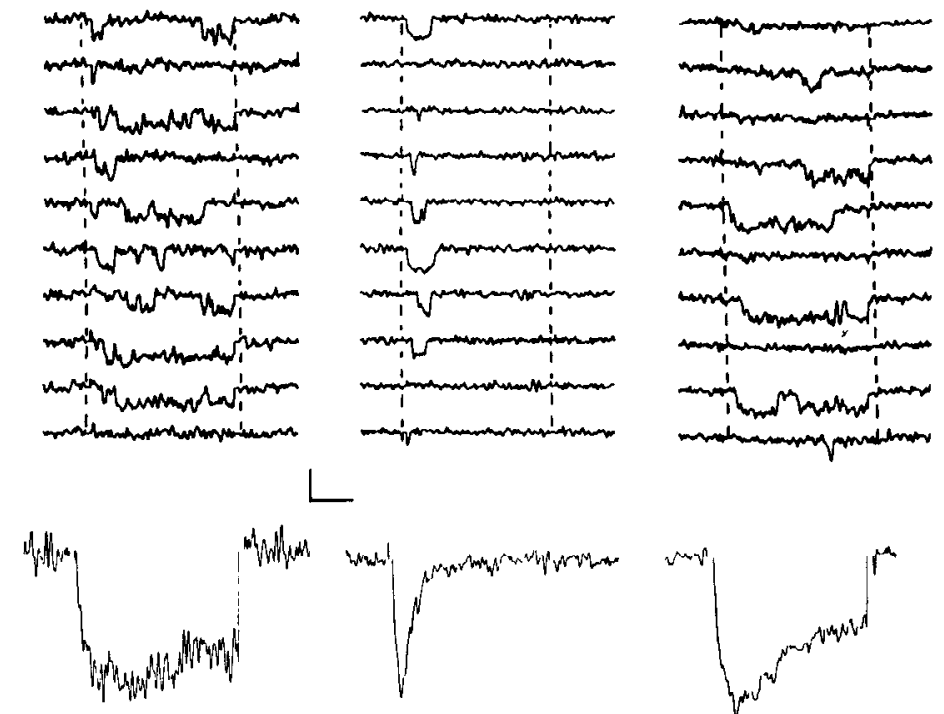
Table 2. Time constant of inactivation and ratio of steady-state $\left(I_{s q}\right)$ to peak current $\left(I_{p}\right)$ for high-MW and unfractionated RNA induced currents

\begin{tabular}{|c|c|c|c|c|}
\hline & \multicolumn{4}{|l|}{$V_{\text {test }}(\mathrm{mV})$} \\
\hline & -20 & -10 & 0 & 10 \\
\hline \multicolumn{5}{|l|}{$\operatorname{tau}$} \\
\hline unfractionated & $1.8 \pm 0.3$ & $1.2 \pm 0.1$ & $1.0 \pm 0.04$ & $0.9 \pm 0.02$ \\
\hline high MW & $4.0 \pm 0.2$ & $2.6 \pm 0.1$ & $3.1 \pm 0.1$ & $2.7 \pm 0.05$ \\
\hline \multicolumn{5}{|l|}{$I_{\mathrm{ss}} / I_{p}$} \\
\hline unfractionated & $0.07 \pm 0.007$ & $0.05 \pm 0.002$ & $0.05 \pm 0.004$ & $0.03 \pm 0.006$ \\
\hline high MW & $0.20 \pm 0.01$ & $0.25 \pm 0.01$ & $0.19 \pm 0.01$ & $0.14 \pm 0.01$ \\
\hline$n$ (unfrac.) & 7 & 7 & 7 & 5 \\
\hline$n$ (high MW) & 8 & 12 & 12 & 11 \\
\hline
\end{tabular}

The time constants and ratios of current amplitudes were obtained as described in Materials and Methods.

fractionated and high-MW induced channels revealed similar time constants. In addition to a single exponential, a linear component was necessary to fit the high-MW data, however. The significance of this component has not yet been investigated since the contribution to the cumulative distribution is small over this time range.

\section{Steady-state inactivation}

In addition to the rate of inactivation, the steady-state voltage dependence of inactivation was also different for $\mathrm{Na}$ currents induced by high-MW RNA. In 2-microelectrode recordings, the voltage for half-maximal steady-state inactivation is $11 \mathrm{mV}$ more positive for high-MW RNA induced $\mathrm{Na}$ currents than for unfractionated RNA induced currents. Figure $6 \mathrm{~A}$ gives the mean value of 2 oocytes from each sample (individual values were -44 and $-42 \mathrm{mV}$ for unfractionated and -33 and $-30 \mathrm{mV}$ for high-MW). In addition, the same relationship is shown below for currents induced by rabbit brain RNA (see Fig. 7B).

A difference in steady-state inactivation was also observed at the single-channel level, as shown in Figure $6 B$. In this case, the $V_{1 / 2}$ for inactivation of high-MW Na channels was $-33 \mathrm{mV}$, while that for unfractionated RNA channels was $-65 \mathrm{mV}$. Consistent results were obtained from the complete voltage range with 2 multichannel patches. It was not possible to obtain complete inactivation curves from patches with a single channel because data acquisition took much longer and patch stability

\begin{tabular}{|c|c|c|c|c|}
\hline \multirow{3}{*}{$\begin{array}{l}\text { Test } \\
\text { potential } \\
(\mathrm{mV}) \\
\end{array}$} & \multicolumn{4}{|c|}{ Mean open time (msec) } \\
\hline & \multicolumn{2}{|c|}{ Unfractionated } & \multicolumn{2}{|l|}{ High MW } \\
\hline & $\begin{array}{l}\text { Cell- } \\
\text { attached }\end{array}$ & Outside-out & $\begin{array}{l}\text { Cell- } \\
\text { attached }\end{array}$ & Outside-out \\
\hline-50 & & $0.15(30)$ & & \\
\hline-40 & & $0.57(315)$ & & $0.44(87)$ \\
\hline-35 & & $0.47(115)$ & & \\
\hline-30 & & $0.47(585)$ & $0.77(261)$ & $0.5 \quad(232)$ \\
\hline-28 & $0.96(214)$ & & & \\
\hline-25 & & $0.78(70)$ & & $0.62(57)$ \\
\hline-20 & $0.93(200)$ & $0.56(863)$ & $1.12(740)$ & \\
\hline-14 & $1.15(159)$ & & & \\
\hline-10 & & $0.61(1002)$ & & \\
\hline
\end{tabular}

Values in parentheses indicate the number of events used to determine each value. Holding potential was $-100 \mathrm{mV}$ in all cases. became a limiting factor. However, in other patches where partial inactivation curves were obtained, substantial inactivation still occurred at $-60 \mathrm{mV}$ for $\mathrm{Na}$ channels from unfractionated RNA.
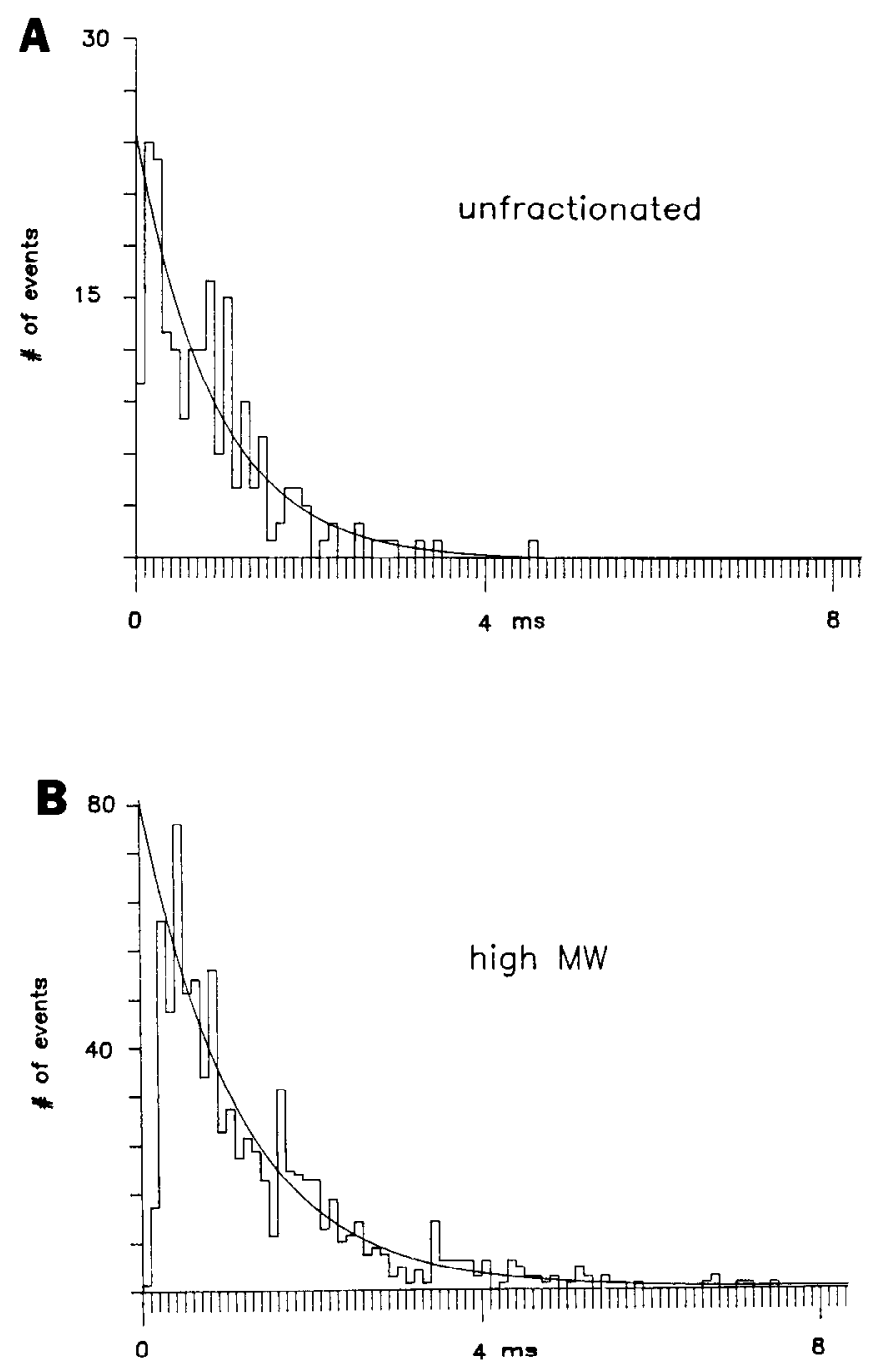

Figure 4. Open time histograms for unfractionated $(A)$ and high-MW $(B)$ rat brain induccd channels. Openings were elicited by depolarizing voltage steps from -100 to $-20 \mathrm{mV}$ in the cell-attached configuration. The smooth curves are fits of a single exponential to the data. The mean open times determined from the fit were $0.9 \mathrm{msec}$ for unfractionated and $1.1 \mathrm{msec}$ for high-MW RNA induced channels. 
A

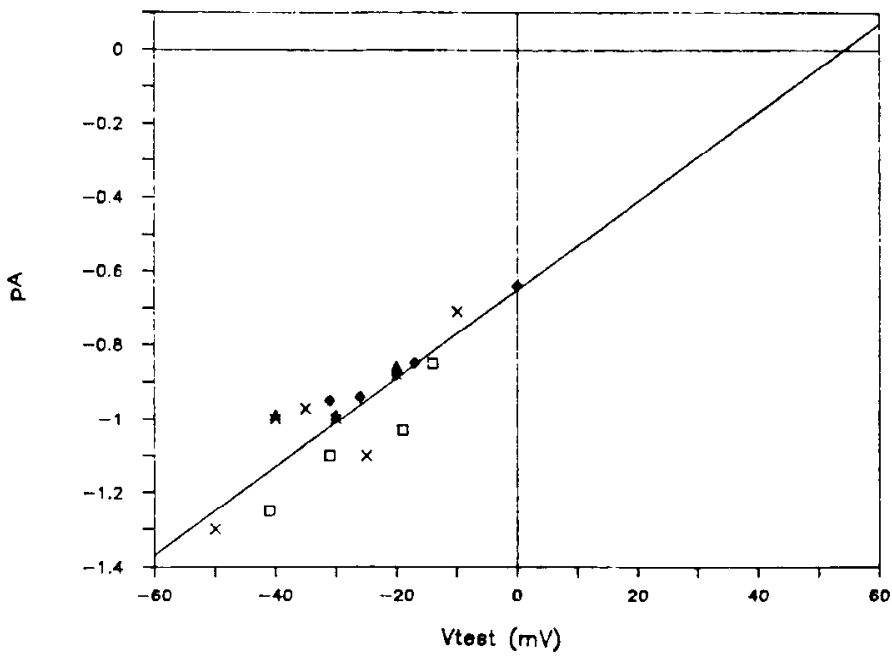

B

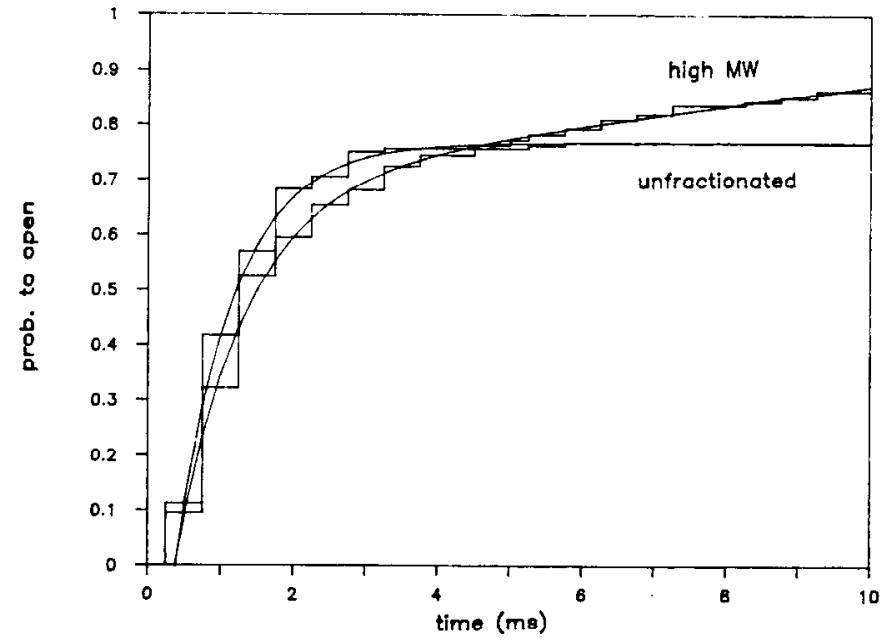

Figure 5. Single-channel current-voltage relationship $(A)$ and cumulative first latency distribution $(B)$ for high-MW and fractionated rat brain RNA induced channels in both cell-attached (cap) and outsideout patch (osop) recording configurations. $A$, Symbols are as follows: $\square$, unfractionated-cap; $x$, unfractionated-osop; $\bullet$, high-MW-cap; and $\boldsymbol{\wedge}$, high-MW-osop. In $A$, the straight line represents a conductance of 12 pS. Current amplitudes at each voltage were obtained by constructing a histogram of amplitudes and fitting a Gaussian distribution. The mean of the Gaussian distribution is plotted at each voltage. The single-channel reversal potential is approximately $+54 \mathrm{mV}$. In $B$, the smooth curves represent fits of single exponentials to the data; the time constant is 0.8 msec for unfractionated and $0.97 \mathrm{msec}$ for high-MW data. The amplitude of the exponential component is 0.77 for the unfractionated distribution and 0.69 for the high-MW distribution. The fit to the highMW data also includes a linear component with a slope of $0.02 / \mathrm{msec}$ and zero-time intercept of 0 . Data are from patches with a single channel as judged by the absence of openings with amplitudes of 2 or more times the unitary amplitude.

\section{Reconstitution of normal inactivation properties}

RNA, particularly the relatively high-MW species $(9 \mathrm{~kb})$ that encode the Na channel $\alpha$-subunit, is quite susceptible to both chemical and enzymatic hydrolysis during experimental manipulations. The smaller currents induced by high-MW RNA presumably arose from such degradation during the sucrose gradient fractionations. We were concerned that the kinetic dif-
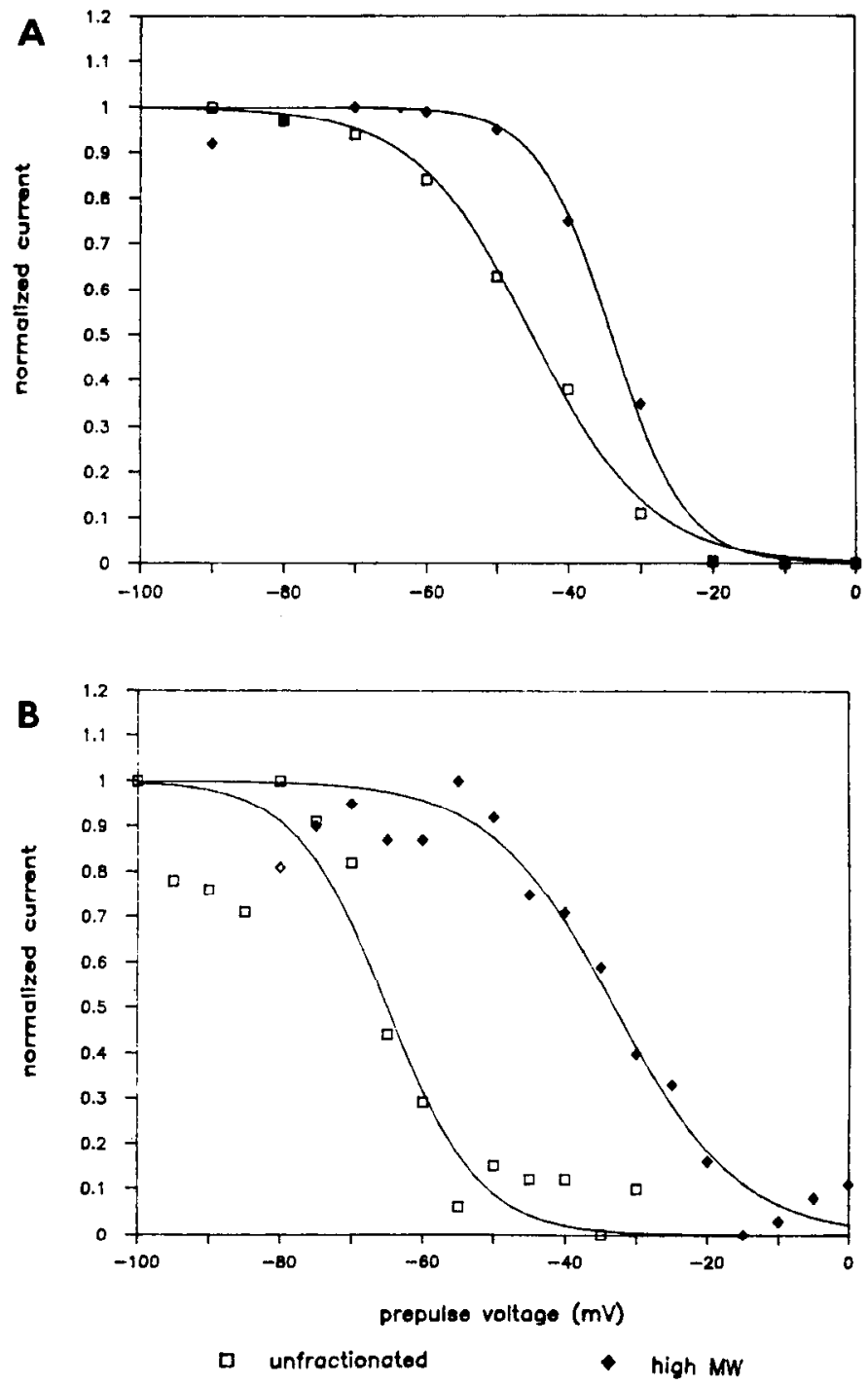

Figure 6. Steady-state inactivation of sodium currents assayed by the 2 microelectrode $(A)$ and outside-out patch single-channel recording techniques $(B)$ with unfractionated $(\square)$ and high-MW rat brain RNA $(\downarrow)$. Inactivation was assayed by measuring current in response to a 12 msec step from -100 to $-10 \mathrm{mV}$, which was preceded by a $50 \mathrm{msec}$ prepulse to various potentials. Current amplitude was normalized to the largest response and plotted against prepulse potential in the figure. The smooth curves are fits to the data of the equation, $I=1 /\{1+$ $\left.\left[\exp \left(V_{m}-V_{1 / 2}\right) / k\right]\right\}$, where $V_{m}=$ membrane potential, $V_{1 / 2}=$ the voltage for half-maximal inactivation, and $k=\mathrm{a}$ slope factor. For the 2-microelectrode data $(A)$, the values for unfractionated RNA were $V_{1 / 2}$ $=-45 \mathrm{mV}$ and $k=8.3 \mathrm{mV}$, and high-MW $V_{1 / 2}=-34 \mathrm{mV}, k=5.1$ $\mathrm{mV}$. For ensemble averages from outside-out patches $(B)$ unfractionated $V_{1 / 2}=-65 \mathrm{mV}, k=6.4 \mathrm{mV}$, high-MW $V_{1 / 2}=-33 \mathrm{mV}, k=8.7 \mathrm{mV}$.

ferences could also arise (by an unknown mechanism) from partial degradation during the sucrose gradient fractionations.

One important series of experiments therefore involved reconstituting the kinetic characteristics of the unfractionated RNA by pooling the sucrose gradient fractions. With either rat brain RNA (Fig. $7 A$ ) or rabbit brain RNA, pooled RNA induced channels with gating characteristics close to those for unfractionated mRNA. Single-channel recordings revealed very few reopenings late during a depolarizing pulse; and averaged current showed inactivation as rapid as for unfractionated RNA.

In a furthcr reconstitution experiment with rabbit brain RNA, we added back only those gradient fractions lower in molecular 
A
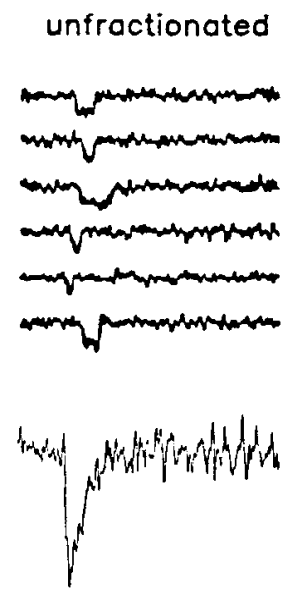

pooled fractions
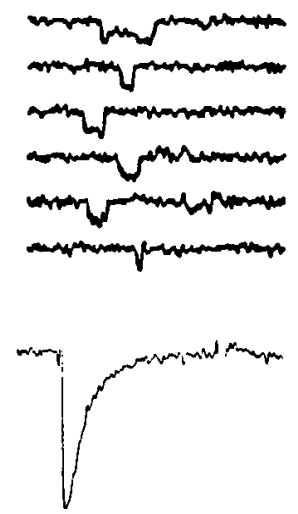

$\mathbf{A}$

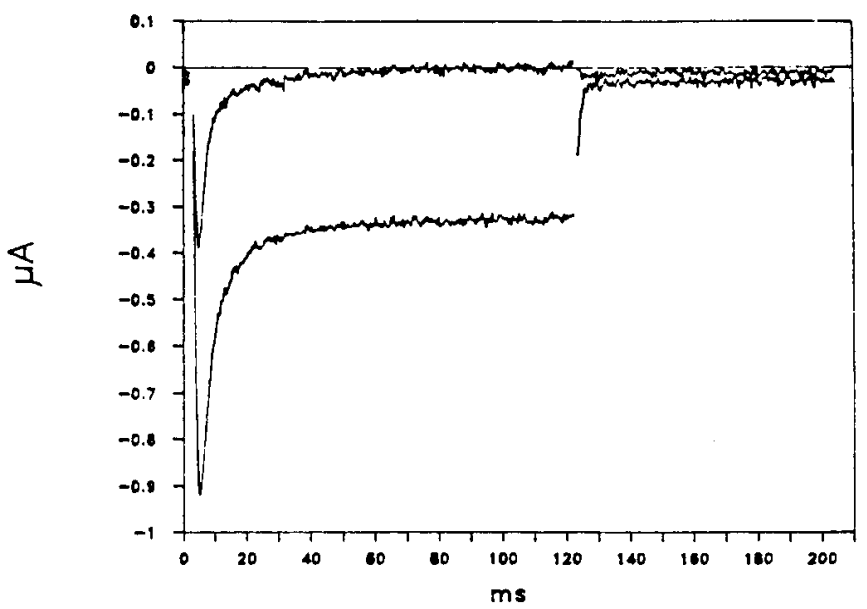

B

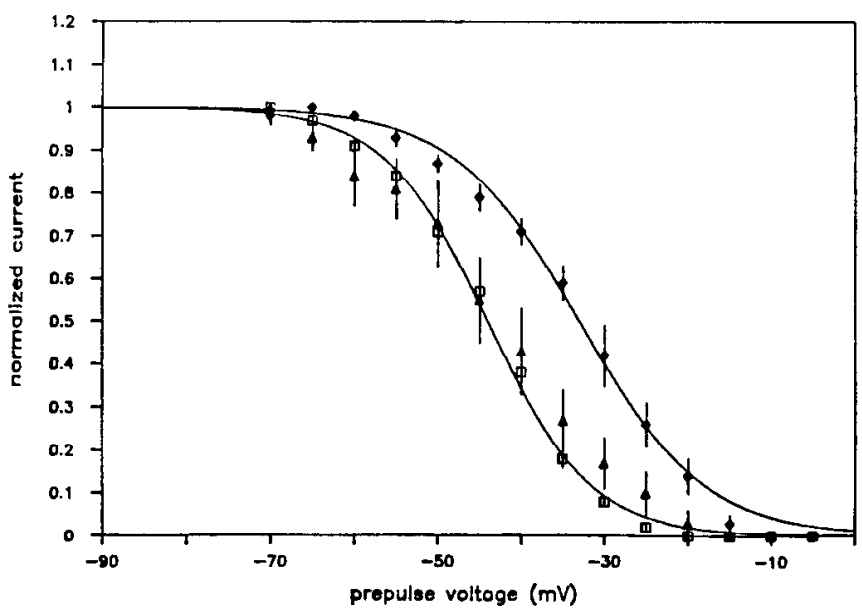

Figure 7. Pooling gradient fractions reconstitutes normal Na channel inactivation. $A$, Single-channel records elicited by $12 \mathrm{msec}$ steps to -20 $\mathrm{mV}$ from a holding potential of $-100 \mathrm{mV}$ for unfractionated and pooled rat brain fractions (cell-attached patches). The dashed line indicates the beginning and end of the depolarizing voltage step. Fractions 1-11 (see Fig. 1) were pooled, and this RNA was injected into oocytes. Below each set of single-channel records is an ensemble average (see Fig. 3) of events with openings. The peaks have been scaled to similar amplitudes to illustrate time course. Calibration bars: $1 \mathrm{pA}, 3 \mathrm{msec}$. $B$, Steady-state voltage dependence of inactivation for unfractionated ( $\square$ ), high-MW $(\triangleleft)$, and pooled (४) rabbit brain RNA fractions (see Fig. 5). Fractions lower in molecular weight than those that gave Na channel signals were pooled with the high-MW fraction. The smooth curves are best fits to the unfractionated and high-MW data. The $V_{1 / 2}$ and $k$ values were as follows: unfractionated, $-44 \mathrm{mV}$ and $6.2 \mathrm{mV}$; high-MW, $-33 \mathrm{mV}$ and $7.5 \mathrm{mV}$; and pooled, $-43 \mathrm{mV}$ and $8.1 \mathrm{mV}$. Values plotted are means \pm SEM of 6,4 , and 3 determinations for unfractionated, high-MW, and pooled RNA induced currents, respectively.

weight than the $\mathrm{Na}$ channel mRNA. The inactivation rates were again comparable to those from unfractionatcd RNA. This result confirms the assumption that the more rapid inactivation is induced by RNA species whose molecular weight is less than that of the Na channel $\alpha$-subunit mRNA.

The steady-state inactivation properties were also reconstituted by these procedures, as shown for rabbit brain RNA in Figure $7 B$. High-MW currents show half inactivation approximately $10 \mathrm{mV}$ more positive than the currents induced by either unfractionated RNA or high-MW RNA that had been pooled
B

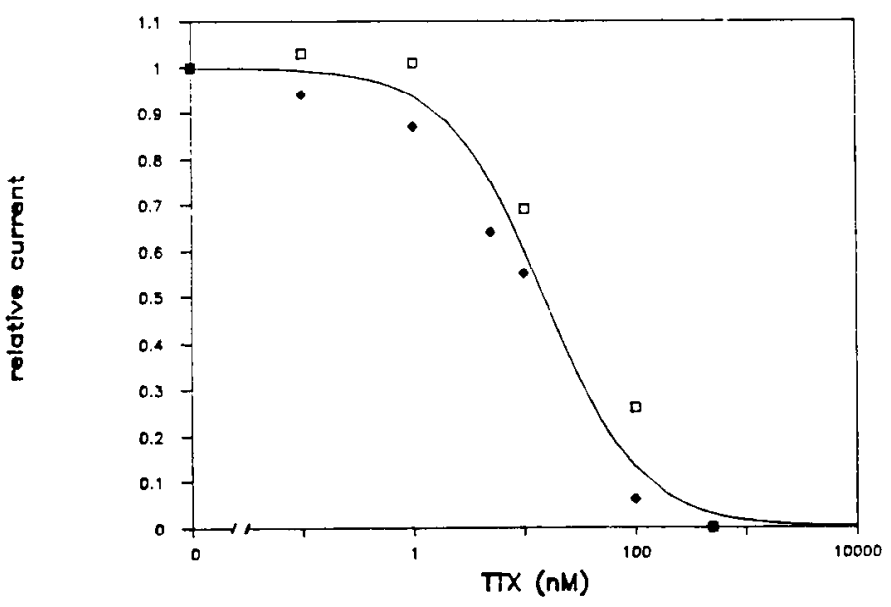

Figure 8. A, Effects of $\alpha$-ScTx (200 nM) on Na currents following injection of high-MW RNA. Currents were elicited by a voltage step from -80 to $-10 \mathrm{mV}$ in a high-MW RNA injected oocyte. $\alpha$-ScTx slows inactivation and induces a maintained component of current. $B$, TTX sensitivity of $\mathrm{Na}$ currents from unfractionated $(\square)$ and high-MW ( ) RNA. The smooth curve is drawn for a single binding site with a $K_{d}$ of $15 \mathrm{nM}$. Fits to the individual sets of data gave a $K_{d}$ of $10 \mathrm{~nm}$ for high-MW RNA and $26 \mathrm{~nm}$ for unfractionated RNA. Data points are averaged from 2 oocytes in each case.

with all fractions lower in molecular weight. These experiments were performed with a single RNA batch that was fractionated, pooled, and tested with oocytes dissected simultaneously from a single female.

The evidence presented above seems to rule out the possibility that the kinetic differences arose because the Na channel RNA was partially degraded beforc injection. Wc werc also concerned about the effects of degradation within the oocyte itself. For instance, the low-MW RNA might protect the Na channel RNA against hydrolysis by oocyte ribonulcease. Again, there is no obvious mechanism that would produce kinetically abnormal channels from partially hydrolyzed RNA; and there are no definitive tests for such an effect. However, we addressed the point by comparing the relative amplitudes of the currents induced by pooled RNA and by high-MW RNA when the injections 
were matched to include the same amount of high-MW RNA. In an experiment with rat RNA, pooled material induced currents $102 \%$ as large as those by high-MW RNA alone; in an experiment with rabbit RNA, the ratio was $82 \%$. These similarities provide a strong argument against the possibility that the low-MW RNA is protecting the high-MW RNA against hydrolysis. In addition, co-injection of yeast tRNA with highMW RNA had no effect.

\section{Neurotoxin sensitivity}

We also investigated pharmacological manipulations of the currents induced by RNA injections. Figure $8 A$ illustrates that $\alpha$ $\mathrm{ScTx}$ dramatically altered the inactivation properties of $\mathrm{Na}$ channels induced by high-MW RNA. The major effect was the appearance of a large maintained component of inward, TTXsensitive current at the end of a $120 \mathrm{~ms}$ depolarization to -10 $\mathrm{mV}$, presumably representing removal of $\mathrm{Na}$ channel inactivation (Koppenhofer and Schmidt, 1968). The small amount of increased inward current at the holding potenital $(-80 \mathrm{mV})$ may also represent removal of inactivation. $\alpha$-ScTx had qualitatively similar effects on $\mathrm{Na}$ currents following injection of unfractionated RNA. Currents became very large in the latter case, however, making it impossible to clamp to the desired membrane potential during the step.

TTX also had very similar effects on currents elicited by unfractionated and by high-MW RNA. Dose-response curves are shown in Figure $8 B$. In all oocytes tested, $500 \mathrm{~nm}$ TTX was sufficient for complete blockade of $\mathrm{Na}$ currents from both highMW and unfractionated RNA.

\section{Discussion}

The major result of this study is that more than one mRNA species appears to be necessary to confer normal inactivation properties on rat and rabbit brain $\mathrm{Na}$ channels expressed in Xenopus oocytes. Channels induced by injection of high-MW RNA, shown to contain the mRNA encoding the $\alpha$-subunit of the channel (Goldin et al., 1986), give rise to $\mathrm{Na}$ currents that inactivate morc slowly than those following injection of unfractionated message. In addition, the steady-state voltage dependence is shifted in the depolarizing direction for high-MW mRNA induced currents compared with those from unfractionated RNA.

\section{Comparison to previous work}

Sumikawa et al. (1984) and Hirono et al. (1985) reported the expression of functional $\mathrm{Na}$ channels following injection of fractionated RNA into Xenopus oocytes. Later results render it likely that the relatively high MW active fractions harbored the $\alpha$-subunit message. For instance, Goldin et al. showed (1) that only an $8-10 \mathrm{~kb}$ fraction induced $\mathrm{Na}$ channels and (2) that only this fraction hybridized with a partial clone for Na channel II. Noda et al. (1986a) have determined the sequences of 3 distinct mRNAs encoding $\alpha$-subunits of voltage-dependent Na channels from rat brain. Full sequence data was given for both type I and type II (the plasmids were termed RI and RII). Complete sequence data have recently been reported for the third type as well (Kayano et al., 1988). Noda et al. (1986b) also reported functional expression of in vitro transcripts of both RI and RII in Xenopus oocytes. The expression of RII was about 500 times greater, however, as judged by the size of the $\mathrm{Na}$ currents reported. Expression of the third type of $\mathrm{Na}$ channel has been reported as well and is similar to RII (Suzuki et al., 1988).
Furthermore, Stuhmer et al. (1987) have extended the electrophysiological characterization of the properties of the channels encoded by the RII sequence and have reported that these channels resemble $\mathrm{Na}$ channels in skeletal muscle and peripheral nerve in several respects. Steady-state inactivation $\left(V_{1 / 2}=-64\right.$ $\mathrm{mV}$ ) is shifled by approximately $+10 \mathrm{mV}$ compared with the values reported for nerve and muscle, however. This value corresponds more closely with the value we obtained followed unfractionated RNA injection than with the value for high-MW RNA injection, where the $V_{1 / 2}$ values are even more positive. It is unclear, however, to what extent the signals due to RII by itself differ from those observed by us with high-MW mRNA since no direct comparison of channel properties, under identicial recording conditions, has yet been presented.

Despite the general agreement, from all studies cited, that RNA encoding the $\alpha$-subunit of RII is sufficient to induce electrically excitable $\mathrm{Na}$ channels in Xenopus oocytes, there have been no previous systematic studies of possible differences between the properties of $\mathrm{Na}$ channels induced by total brain RNA and by samples more highly enriched for the $\alpha$-subunit. The brief report by Noda et al. (1986b), however, stated that coinjected RNA of lower MW than the $\alpha$ message "failed to enhance the TTX-sensitive response" induced by SP6-synthesized RII message. In addition, Stuhmer et al. (1987) noted that the patch-clamp recordings from such oocytes seemed very similar to those obtained with poly $(\mathrm{A}+) \mathrm{RNA}$.

\section{Molecular basis for kinetic differences}

What is the explanation for the differences between Na channels expressed in oocytes following high-MW versus unfractionated RNA injections? We think it most likely that the differences are due either (1) to assembly of complexes containing $\beta 1$ and/or $\beta 2$ subunits when unfractionated RNA is injected or (2) to posttranslational modifications of some sort by components encoded in the low-MW RNA (see Costa et al., 1982; Costa and Catterall, 1984a, b).

Whether smaller subunits are necessary, or even present, may depend on the particular preparation. It has been demonstrated quite convincingly that the $\mathrm{Na}$ channel from eel electroplax consists of a single large polypeptide (Agnew et al., 1980) and that this protein is sufficient to reconstitute a functional voltagedependent Na channel (Rosenberg et al., 1984). The composition of $\mathrm{Na}$ channels from rat sarcolemma and synaptosomes seems to be more complex, however; 2 or more small subunits are present (Hartshorne et al., 1982; Barchi, 1983). One of these subunits appears necessary for reconstitution of the active channel from the purified synaptosome protein (Messner et al., 1986). The results of Noda et al. (1986b) indicate that no other subunits, barring any endogenous oocyte contribution, are necessary for assembly of a functional channel in vivo, however. It will be unclear how our results bear on these findings until we know where the $\beta$-subunit mRNAs sediment in our sucrose gradients.

Since Noda et al. (1986b) report that in vitro transcripts of RI plasmids give much weaker signals in oocytes than in vitro transcripts of RII, one could conceive that the main component of the signal due to injection of unfractionated mRNA is due to RI complexes that assemble with $\beta 1$ - and $\beta 2$-subunits, whereas the signal from high-MW RNA is due to RII $\alpha$-subunits. We consider this is unlikely, however, in view of the report of Grubman et al. (1987) that there is significantly more RII mRNA in total rat brains than RI mRNA. In addition, since the ampli- 
tudes of the currents were comparable for pooled versus highMW RNA induced currents, it appears unlikely that we are reconstituting a different channel when we combine sucrose gradient fractions.

The high-MW RNA is highly enriched $(\approx 50$-fold) for $\mathrm{Na}$ channel mRNA, but this fraction certainly encodes other proteins as well. Perhaps one or more of these proteins, or an endogenous oocytc protein, influence channel kinetics. Given the complex competition among injected RNAs for translation machinery, it seems possible (though unlikely) that this factor could be suppressed by unfractionated or pooled RNA (Richter and Smith, 1981).

\section{Are $\beta$-subunits involved in neurotoxin sensitivity?}

Messner and Catterall (1986) have suggested that the $\beta 1$-subunit of the rat brain $\mathrm{Na}$ channel complex is necessary for the integrity of the STX/TTX binding site on the solubilized synaptosomal channel protein. In addition, Sharkey et al. (1984) have shown that a photoaffinity derivative of $\alpha$-ScTx preferentially binds to the $\beta 1$-subunit, although in this case there is also some binding to $\alpha$. Because the $\beta$-subunits are lower-molecular-weight proteins than the $\alpha$-subunit (21-22 vs $220 \mathrm{kDa}$ for the peptide portions), it is likely these small proteins are encoded in smallermolecular-weight RNAs; one might, therefore, expect high-MW RNA to encode $\mathrm{Na}$ channels that are resistant to these toxins (the possibility of $\beta$-subunits being encoded in large mRNAs is still logically possible). However, both $\alpha$-ScTx and TTX affected $\mathrm{Na}$ channels induced by high-MW RNA similarly to their actions on channels induced by unfractionated message. Noda et al. (1986b) have reported a $K_{d}$ of $14 \mathrm{nM}$ for TTX block of Na currents following injection of in vitro transcripts of RII as well. It is possible that the oocyte contributes the equivalent of a $\beta$ subunit or that the behavior of the solubilized protein differs from its behavior in the native lipid environment, despite the fact that the solubilized Electrophorus $\alpha$-subunit binds TTX when reconstituted into lipid vesicles (Miller et al., 1983). The apparent discrepancies call for further study.

\section{Possible implications}

Aldrich and Stevens (1987) have noted a difference in the channel open time duration in cell-attached patches compared with that reported by other groups working with excised patches (see Horn and Vandenberg, 1984; Vandenberg and Horn, 1984). They also note that channel duration increases when they excise a patch, possibly indicating the loss of some cellular component involved in determining open channel duration. Increases in channel duration could lead to slower inactivation rates. The dominant effect under our test conditions, however, appears to he a greater probability for channels to reopen during a pulse in the majority of patches; we observed no major difference in mean open times (see Table 3).

It should be noted, however, that we have not systematically examined channel open times at all voltages and in all configurations. We therefore cannot definitively say whether there are small differences in open time for unfractionated and high-MW channels or between excised and cell-attached patches. These differences, if they exist, could contribute to the effects we have seen. We emphasize, however, it is unlikely such changes underlie the difference in macroscopic inactivation kinetics between channels induced by high-MW RNA and by unfractionated RNA. For instance, if channel open duration determined the macroscopic decay rate for high-MW RNA channels, then the open time would be approximately $4 \mathrm{msec}$ at $-20 \mathrm{mV}$ (see Tables 2 and 3). In fact, our data show a value of approximately $1 \mathrm{msec}$. It seems more likely that reopening rates, rather than closing rates, account for the differences between channels induced by high-MW RNA and by unfractionated RNA.

The existence of a factor involved in regulating $\mathrm{Na}$ channel kinetics either at the level of channel assembly or after insertion into the membrane is not unreasonable. Sigel (1987a) has recently characterized the properties of $\mathrm{Na}$ currents following injection of chick skeletal muscle RNA into Xenopus oocytes. For the single-channel level he reports 2 kinetics states of $\mathrm{Na}$ channels that may arise from 2 separate channels or from switching of a single channel type between 2 different gating modes. [Following injection of chick brain RNA, Sigel (1987b) found a homogeneous population, however.] The idea of gating modes has been described by Hess et al. (1984) for cardiac L-type calcium channels and by Patlak and Ortiz $(1985,1986)$ for both cardiac and skeletal muscle $\mathrm{Na}$ channels. It is possible that a cellular component other than the $\beta$-subunits regulates channel kinetics and that the mRNA encoding this factor is removed by our fractionation.

One final point involves the microscopic rate constants that underlie the change studied here. For agents such as NBA that slow or remove $\mathrm{Na}$ channel inactivation, there is a dramatic increase in channel open times (Patlak and Horn, 1982). In this paper we report similar macroscopic observations. However, it appears these effects arise from an increased probability for channels to reopen during a pulse, suggesting that the inactivated state may no longer be absorbing. This implies that a protein, encoded by an mRNA smaller than that for the $\alpha$-subunit, may be necessary for the channel to rcmain in the inactivated state. Further experiments may lead to a better understanding of the molecular mechanism by which channel inactivation takes place.

\section{References}

Agnew, W. S. (1984) Voltage-regulated sodium channel molecules. Annu. Rev. Physiol. 46: 517-530.

Agnew, W. S., A. C. Moore, S. R. Levinson, and M. A. Raftery (1980) Identification of a large peptide associated with the tetrodotoxin binding protein from Electrophorus electricus. Biochem. Biophys. Res. Commun. 92: 860-866.

Aldrich, R. W., and C. F. Stevens (1987) Voltage-dependent gating of single sodium channels from mammalian neuroblastoma cells. J. Neurosci. 7: 418-431.

Auld, V. J., A. L. Goldin, D. S. Krafte, J. Marshall, J. M. Dunn, W. A. Catterall, H. A. Lester, N. Davidson, and R. J. Dunn (1988) A rat brain Na channel $\alpha$ subunit with novel gating properties. Neuron (in press).

Barchi, R. L. (1983) Protein components of the purified sodium channel from rat skeletal muscle sarcolemma. J. Neurochem. 40: 13771385.

Costa, M. R. C., and W. A. Catterall (1984a) Cyclic AMP-dependent phosphorylation of the $\alpha$ subunit of the sodium channel in synaptic nerve ending particles. J. Biol. Chem. 259: 8210-8218.

Costa, M. R. C., and W. A. Catterall (1984b) Phosphorylation of the $\alpha$ subunit of the sodium channel by protein kinase C. Cell Mol. Neurobiol. 4: 291-297.

Costa, M. R. C., J. E. Casnellie, and W. A. Catterall (1982) Selective phosphorylation of the $\alpha$ subunit of the sodium channel by cAMPdependent protein kinase. J. Biol. Chem. 257: 7918-7921.

Dierks, P. A., A. van Ooyen, N. Mantei, and C. Weissmann (1981) DNA sequences preceding the rabbit $\beta$ globin gene are required for formation in mouse $L$ cells of $\beta$ globin RNA with the correct $5^{\prime}$ terminus. Proc. Natl. Acad. Sci. USA 78: 1411-1415.

Finkel, A. S., and P. W. Gage (1985) Conventional voltage clamping with two intracellular microelectrodes. In Voltage and Patch Clamp- 
ing with Microelectrodes, T. G. Smith Jr., H. Lecar, S. J. Redmann, and P. W. Gage, eds., pp. 47-94, Waverly, Baltimore, MD.

Goldin, A. L., T. Snutch, H. Lubbert, A. Dowsett, J. Marshall, V. Auld W. Downey, L. C. Fritz, H. A. Lester, R. Dunn, W. A. Catterall, and N. Davidson (1986) Messenger RNA coding for only the $\alpha$ subunit of the rat brain $\mathrm{Na}$ channel is sufficient for expression of functional channels in Xenopus oocytes. Proc. Natl. Acad. Sci. USA 83: 75037507.

Gonoi, T., and B. Hille (1987) Gating of Na channels. Inactivation modifiers discriminate among models. J. Gen. Physiol. 89: 253-274.

Grubman, S. A., S. S. Cooperman, M. P. Begley, J. L. Weintraub, R. H. Goodman, and G. Mandel (1987) Tissue-specific expression of genes encoding the rat voltage-gated sodium channel. In Molecular Biology of Ion Channels, W. Agnew, ed., Academic, New York (in press).

Hamill, O. P., A. Marty, E. Neher, B. Sakmann, and F. Sigworth (1981) Improved patch-clamp techniques for high resolution current recording from cells and cell-free patches. Pfluegers Arch. 391: 85-100.

Hartshorne, R. P., D. J. Messner, J. C. Coppersmith, and W. A. Catterall (1982) The saxitoxin receptor of the sodium channel from rat brain; cvidence for two non-identical subunits. J. Biol. Chem. 257: 1388813891.

Hess, P., J. B. Lansman, and R. W. Tsien (1984) Different modes of $\mathrm{Ca}$ channel gating behavior favoured by dihydropyridine $\mathrm{Ca}$ agonists and antagonists. Nature 311: 538-544.

Hirono, C., S. Yamagashi, R. Ohara, Y. Hisanaga, T. Nakayama, and H. Sugiyama (1985) Characterization of $m R N A$ responsible for induction of functional sodium channels in Xenopus oocytes. Brain Res. 359: 57-64.

Hodgkin, A. L., and A. F. Huxley (1952) A quantitative description of membrane current and its application to conduction and excitation in nerve and muscle. J. Physiol. (Lond.) 117: 500-544.

Horn, R., and C. A. Vandenberg (1984) Statistical properties of single sodium channels. J. Gen. Physiol. 84: 505-534.

Kayano, T., M. Noda, V. Flockerzi, H. Takahashi, and S. Numa (1988) Primary structure of rat brain sodium channel III deduced from the cDNA sequence. FEBS Lett. 228: 187-194.

Kegel, D. R., B. F. Wolf, R. E. Sheriden, and H. A. Lester (1985) Software for electrophysiological experiments with a personal computer. J. Neurosci. Methods 12: 317-330.

Koppenhofer, E., and H. Schmidt (1968) Die Wirkung von Skorpiongift auf die Ionenstrome des Ranvierschen Schnurrings. I. Die Permeabilitaten PNa und PK. Pfluegers Arch. 303: 133-149.

Krafte, D., J. Leonard, T. Snutch, N. Davidson, and H. A. Lester (1987a) Slowly inactivating sodium currents from injection of high molecular weight rat brain RNA into Xenopus oocytes. Biophys. J. 51:194a.

Krafte, D. S., T. P. Snutch, J. P. Leonard, N. Davidson, and H. A. Lester (1987b) More than one RNA species is involved in controlling inactivation of rat brain $\mathrm{Na}$ channcls cxpresscd in Xenopus oocytes. J. Neurosci. 13: 91.

Leonard, J., T. Snutch, H. Lubbert, N. Davidson, and H. A. Lester (1986) Macroscopic Na currents with gigaohm seals on mRNAinjected Xenopus oocytes. Biophys. J. 49: 386a.

Leonard, J. P., J. Nargeot, T. P. Snutch, N. Davidson, and H. A. Lester (1987) Ca channels induced in Xenopus oocytes by rat brain mRNA J. Neurosci. 7:875-881.

Maniatis, T.. E. F. Fritsch, and J. Sambrook (1982) Molecular Cloning Cold Spring Harbor Laboratory, Cold Spring Harbor, NY.

Messner, D. J., and W. A. Catterall (1986) The sodium channel from rat brain. Role of the $\beta 1$ and $\beta 2$ subunits in saxitoxin binding. J. Biol. Chem. 261: 211-215.

Messner, D. J., D. J. Feller, T. Scheuer, and W. A. Catterall (1986) Functional propertics of rat brain sodium channcls lacking the $\beta 1$ or $\beta 2$ subunit. J. Biol. Chem. 261: 14882-14890.
Methfessel, C., V. Witzman, B. Sakmann, T. Takahashi, M. Mishina, and S. Numa (1986) Patch clamp measurements on Xenopus laevis oocytes: Currents through endogenous channels and implanted acetylcholine receptors and $\mathrm{Na}$ channels. Pfluegers Arch. 407: 577-588.

Miller, J. A., W. S. Agnew, S. R. Levinson (1983) Principal glycopeptide of the tetrodotoxin/saxitoxin binding protein from Electrophorus electricus: Isolation and partial chemical and physical characterization. Biochemistry 22: 462-470.

Noda, M., S. Shimizu, T. Tanabe, T. Takai, T. Kayano, T. Ikeda, H. Takahashi, H. Nakayama, Y. Kanaoka, N. Minamino, K. Kangawa, H. Matsuo, M. A. Raftery, T. Hirose, S. Inayama, H. Hayahsida, T. Miyata, and S. Numa. (1984) Primary structure of Electrophorus electricus sodium channel deduced from cDNA sequence. Nature 312 : 121-127.

Noda, M., T. Ikeda, T. Kayano, H. Suzuki, H. Takashima, M. Kurasaki H. Takahashi, H. Nakayama, and S. Numa (1986a) Existence of distinct sodium channel messenger RNAs in rat brain. Nature 320 . 188-192.

Noda, M., T. Ikeda, T. Kanyano, H. Suzuki, H. Takashima, H. Takahashi, M. Kuno, and S. Numa (1986b) Expression of functional sodium channcls from cloncd cDNA. Nature 322: 826-828.

Patlak, J., and R. Horn (1982) Effect of N-bromoacetamide on single sodium channel currents in excised membrane patches. J. Gen. Physiol. 79: 333-351.

Patlak, J., and M. Ortiz (1985) Slow currents through single sodium channels of the adult rat heart. J. Gen. Physiol. 86: 89-104.

Patlak, J., and M. Ortiz (1986) Two modes of gating during late $\mathrm{Na}^{+}$ channel currents in frog sartorius muscle. J. Gen. Physiol. 87: 305326.

Richter, J. D., and L. D. Smith (1981) Differential capacity for translation and lack of competition between mRNAs that segregate to free and membrane-bound polysomes. Cell 27: 183-191.

Rosenberg, R. L., S. A. Tomiko, and W. Agnew (1984) Single-channel properties of the reconstituted voltage-regulated $\mathrm{Na}$ channel from the electroplax of Electrophorus electricus. Proc. Natl. Acad. Sci. USA 81: 5594-5598.

Schmidt, J. W., and W. A. Catterall (1986) Biosynthesis and processing of the $\alpha$ subunit of the voltage-sensitive sodium channel in rat brain neurons. Cell 46: 437-445.

Sharkey, R. G., D. A. Beneski, and W. A. Catterall (1984) Differential labeling of the $\alpha$ and $\beta 1$ subunits of the sodium channel by photoreactive derivatives of scorpion toxin. Biochemistry 23: 6078-6086.

Sigel, E. (1987a) Properties of single sodium channels translated by Xenopus oocytes after injection with messenger ribonucleic acid. J. Physiol. (Lond.) 386: 73-90.

Sigel, E. (1987b) Effects of veratidine on single neuronal sodium channels expressed in Xenopus oocytes. Pfluegers Arch. 410: 112-120.

Stuhmer, W., C. Methfessel, B. Sakmann, M. Noda, and S. Numa (1987) Patch clamp charactcrization of sodium channcls expressed from rat brain cDNA. Eur. Biophys. J. 14: 131-138.

Sumikawa, K., I. Parker, and R. Miledi (1984) Partial purification and functional expression of brain mRNAs coding for neurotransmitter receptors and voltage-operated channels. Proc. Natl. Acad. Sci. USA 81: 7994-7998.

Sutton, F., N. Davidson, and H. Lester (1987) Tetrodotoxin-sensitive voltage-dependent $\mathrm{Na}$ currents recorded from Xenopus oocytes injected with mammalian cardiac muscle RNA. Mol. Brain Res. (in press).

Suzuki, H., S. Beckh, H. Kubo, N. Yahagi, H. Ishida, T. Kayano, M. Noda, and S. Numa (1988) Functional expression of cloned cDNA encoding sodium channel III. FEBS Lett. 228: 195-200.

Vandenberg, C. A., and R. Horn (1984) Inactivation viewed through single sodium channels. J. Gen. Physiol. 84: 535-564. 